\title{
Evaluation of Coupled Precipitator Two
}

by

M. E. Stone

Westinghouse Savannah River Company

Savannah River Site

Aiken, South Carolina 29808

This paper was prepared in connection with work done under the above contract number with the U. S. Department of Energy. By acceptance of this paper, the publisher and/or recipient acknowledges the U.S. Government's right to retain a nonexclusive, royalty-free license in and to any copyright covering this paper, along with the right to reproduce and to authorize others to reproduce all or part of the copyrighted paper. 


\section{DISCLAIMER}

This report was prepared as an account of work sponsored by an agency of the United States Government. Neither the United States Government nor any agency thereof, nor any of their employees, makes any warranty, express or implied, or assumes any legal liability or responsibility for the accuracy, completeness, or usefulness of any information, apparatus, product, or process disclosed, or represents that its use would not infringe privately owned rights. Reference herein to any specific commercial product, process, or service by trade name, trademark, manufacturer, or otherwise does not necessarily constitute or imply its endorsement, recommendation, or favoring by the United States Government or any agency thereof. The views and opinions of authors expressed herein do not necessarily state or reflect those of the United States Government or any agency thereof.

This report has been reproduced directly from the best available copy.

Available to DOE and DOE contractors from the Office of Scientific and Technical Information, P.O. Box 62, Oak Ridge, TN 37831; prices available from (615) 576-8401.

Available to the public from the National Technical Information Service, U.S. Department of Commerce; 5285 Port Royal Road, Springfield, VA 22161. 


\section{DISCLAIMER}

Portions of this document may be illegible in electronic image products. Images are produced from the best available original document. 
WSRC-TR-99-00284, Rev. 0

Keywords: Americium, Curium,

Precipitation, Vitrification $\mathrm{Am} / \mathrm{Cm}$

Retention: Permanent

\section{EVALUATION OF COUPLED PRECIPITATOR TWO (U)}

M. E. Stone

Publication Date: August 17, 1999

8

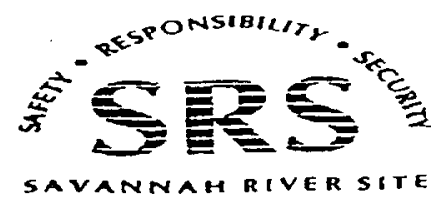




\section{APPROVALS}

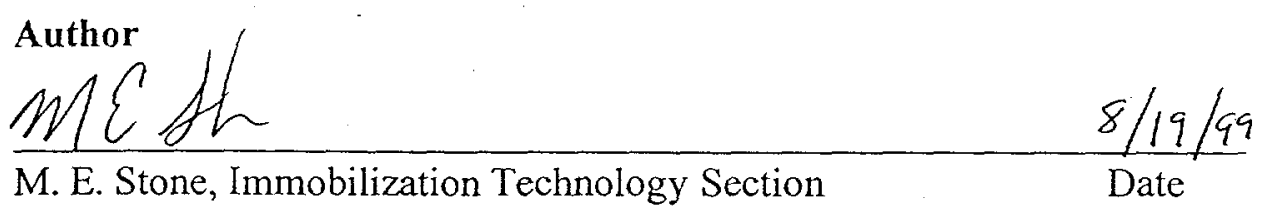

\section{Technical Reviewer}

\begin{tabular}{cc} 
AWW & $8 / 20 / 99$ \\
\hline D. C. Witt, Immobilization Technology Section & Date
\end{tabular}

\section{Approvals}

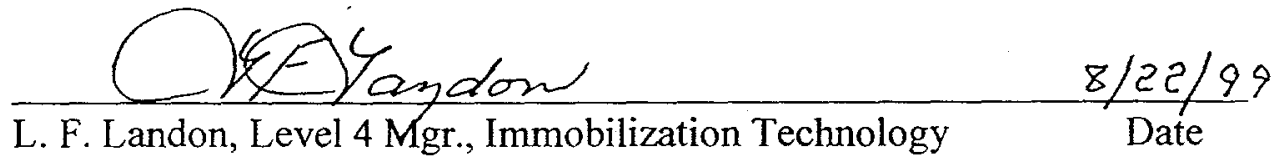




\section{TABLE OF CONTENTS}

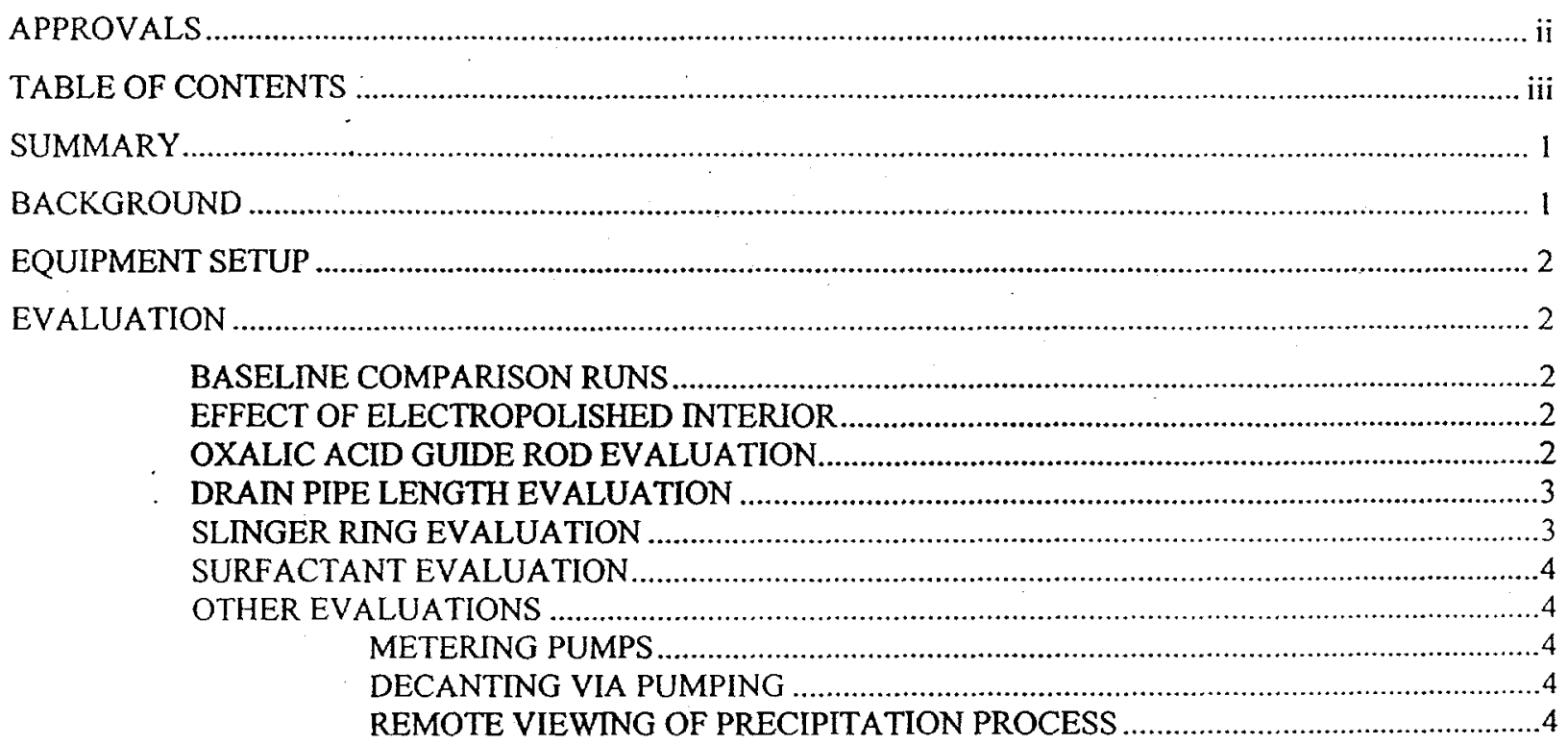

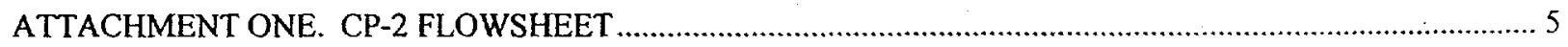

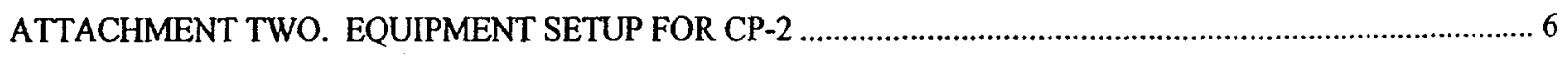

ATTACHMENT THREE. OXALIC ACID GUIDE ROD AND ENTRY TUBE. …............................................ 7

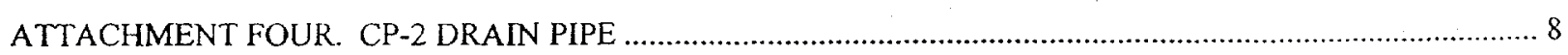

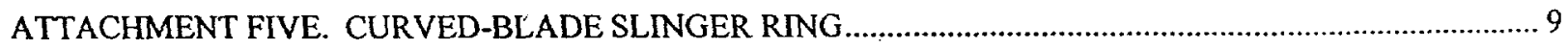

ATTACHMENT SIX. FLOW DISTRIBUTION OF SLINGER RING .......................................................... 10 
WSRC-TR-99-00284, Rev. 0

Page 1

References: SRT-AMC-99-0034, WSRC-NB-99-00109.

\section{SUMMARY}

The offline testing of the Coupled Precipitator Two (CP-2) has been completed. The tests were conducted per SRT-AMC-99-0034 and are documented in laboratory notebook WSRC-NB-9900109. The tests were conducted at an offline test rack near the Drain Tube Test Stand facility in 672-T.

The changes made to the design of the vessel and equipment have improved the performance of the precipitator. The polished interior significantly reduced film formation, the curved slinger ring eliminated free-flowing solids holdup, and the longer drain pipe reduced splashing during the transfer of the water rinse to the melter.

The oxalic acid guide rod successfully prevented splattering during the precipitation process, but led to a greater potential for solids to build up due to the precipitation process occurring directly on the guide rod. The impact of surfactant in the water rinse was not significant at low concentrations.

It is recommended that the electropolished interior, curved blade slinger ring, and longer drain pipes be incorporated in the design of the final precipitator vessel. Use of the guide rod, surfactant, and spray nozzles is not recommended.

\section{BACKGROUND}

Americium and curium are currently being stored in a nitric acid solution in F-canyon. The $\mathrm{Am} / \mathrm{Cm}$ program will stabilize this material in glass for safe storage and transportation. The current flowsheet requires an oxalate precipitation and washing process to denitrate the feed prior to vitrification. This step will be performed on a batch basis with each precipitation batch equal to one melter run. The precipitation will be performed in a "coupled precipitator" specifically designed to precipitate and wash the feed solution, decant excess solution, and transfer the oxalate to the melter for vitrification.

Coupled Precipitator One (CP-1) was designed, fabricated, and tested in 1998 exceeding all performance criteria. A spare vessel was desired to prevent a failure from causing a prolonged schedule delay. The operating experience gained from $\mathrm{CP}-1$ was used to make minor improvements in the design of the new vessel, CP-2.

The most significant change was to the surface finish of the vessel to reduce the amount of film formation. Other changes to the vessel included moving all penetrations $1 / 2$ " closer to the center of the vessel and designing the top to allow equipment changes and better viewing of the interior.

The oxalic acid addition method, slinger ring, and drain pipe were also modified based on the operating experience gained with $\mathrm{CP}-1$. These modifications were tested during the offline evaluation of CP-2. 
The testing of $\mathrm{CP}-2$ was performed to compare the performance of the new vessel versus the performance of $\mathrm{CP}-1$. Due to the nature of the comparisons, qualitative means were used for all evaluations.

\section{EQUIPMENT SETUP}

CP-2 was tested at the same offline location in $672-\mathrm{T}$ used for initial testing of CP-1. The equipment setup is shown in Attachment One. Initial installation of the vessel was performed to match CP-1 as closely as possible to perform a baseline comparison. Installation of modified equipment was performed after two baseline runs, as shown in Attachment Two.

\section{EVALUATION}

\section{BASELINE COMPARISON RUNS}

Runs CP2-1 and CP2-2 were performed with the identical setup as CP-1 to allow a baseline comparison. The tank penetrations on CP-2 are $1 / 2$ " closer to the slinger ring, resulting in slightly larger shadows during the water rinse. In addition, the $1 / 2$ " diameter (as compared to $3 / 8$ ") decant tube led to a larger amount of free-flowing solids holdup behind the tube, but overall performance of CP-2 was very similar to CP-1.

\section{EFFECT OF ELECTROPOLISHED INTERIOR}

The primary goal for testing CP-2 was to determine the impact of a polished interior on holdup in the vessel. The amount of film buildup was significantly reduced by the polished surfaces, but a film did form over all components wetted by the process solution. The film buildup on unpolished vessel penetrations, such as the decant tube was similar to the buildup in CP-1 while the polished interior walls had a much thinner film that flaked off in many places. The electropolishing service was very inexpensive $(<500)$, therefore it is recommended that all interior surfaces of the final precipitator vessel be electropolished.

\section{OXALIC ACID GUIDE ROD EVALUATION}

The amount of film deposits was dramatically reduced in CP-1 by changing the addition method for the oxalic acid from a vapor space addition to a subsurface addition to avoid splashing and splatter during the addition. However, subsurface addition represents a greater potential for line pluggage and backflow than feeding solution into the vapor space. The splashing noted in CP-1 was primarily due to drops from the feed tube free falling onto the liquid surface. A guide rod (Attachment Three) was evaluated to determine if the splatter and splashing could be avoided without a subsurface feed.

The guide rod was very effective in preventing splatter and splashing during the addition. The oxalic acid ran down the rod and flowed smoothly into the surrogate feed solution without splashing. Particle size and settled solids volume were not impacted by the feed addition method. Buildup on the guide rod was similar to buildup on the subsurface feed tube over most of the tube. However, one chunk of material ( 2 grams) adhered to the guide rod during CP2-2 and grew in size with each subsequent run. 
The primary drawback of the guide rod versus a subsurface feed is the location where the precipitation process occurs. The kinetics of the reaction are extremely fast and oxalate formation occurs at the point of contact between the surrogate solution and oxalic acid. With the subsurface feed line, the point of contact remains constant while the point of contact is the solution surface with the guide rod and moves up the tank as the level increases. The shear rate from agitation decreases with tank height until the second impeller is reached. The chunk observed on the guide rod formed just underneath the second impeller in a region where precipitation occurs under the lowest shear rates.

Use of the guide rod as currently configured is not recommended. Additional testing is possible to determine if an electropolished guide rod or a slight lowering of the second impeller reduces the risk of depositing material on the guide rod. However, approximately 40 runs have been performed in CP-1 to date without pluggage in the subsurface feed tube and it is recommended that the subsurface feed line be utilized.

\section{DRAIN PIPE LENGTH EVALUATION}

During the transfer of oxalate to the melter, significant amounts of splashing was occurring during the water rinse. The drain pipe was machined with a knife-edge (Attachment Four) to reduce wicking and lengthened to reduce the free fall height of the water rinse. A nominal 3.5" length drain pipe was installed in place of the 2" drain pipe after run CP2-2. The height of the precipitator was not adjusted, therefore the clearance between the precipitator to the melter was reduced from $2 "$ to $1 / 2 "$.

The amount of wicking and splashing during the water rinse was significantly reduced by the longer pipe and the closer coupling to the melter. The primary benefit of the longer drain pipe is to reduce the amount of space between the end of the drain pipe and the top flange of the melter. The splashing observed from the vessel is caused by the free fall of the drops during the water rinse. The knife-edge on the outlet reduced the amount of wicking during the flush process.

It is recommended that the precipitator drain pipe be designed to couple as closely as possible to the melter vessel to reduce splashing and designed with a knife-edge outlet to reduce wicking.

\section{SLINGER RING EVALUATION}

The precipitator was originally setup with a straight 4-bladed slinger ring similar to CP-1. During CP2-1, a large amount of free-flowing solids remained after the water rinse. A majority of the rinse water fed to the precipitator was deposited within a 4". arc along the front of the vessel. Repositioning the rinse addition port to flow directly onto the agitator shaft above the slinger ring greatly improved distribution and led to results similar to CP-1 with free-flowing solids remaining only behind shadows due to tank penetrations. The straight-bladed slinger ring still fed most of the water in a small arc.

A slinger ring with curved blades (Attachment Five) was installed prior to CP2-4. The curved blades led to better distribution of the rinse and eliminated holdup of free-flowing solids during CP2-4 and all subsequent runs. The curved-blade design still led to an area in the tank with a 
higher flush flowrate, as shown in Attachment Six. Positioning the tank penetrations in the area of highest flush flow would significantly reduce shadowing.

It is recommended that the flush be directed onto the agitator shaft just above a curved blade slinger ring. It is also recommended that tank penetrations which interfere with the slinger ring be positioned where flowrate is highest.

\section{SURFACTANT EVALUATION}

The addition of surfactant in the water rinse was evaluated during runs CP2-8 and CP2-9. 100 PPM of IIT-747 was added to the water rinse during these runs. Improvement in flushing performance was marginal. The performance of the curved blade slinger ring in removing the free-flowing solids from the vessel without surfactant is satisfactory and only marginally improved with the surfactant, therefore addition of surfactant is not recommended.

\section{OTHER EVALUATIONS}

During the testing of $\mathrm{CP}-2$, several evaluations were performed on auxilary equipment.

\section{METERING PUMPS}

Cole-Parmer® Digital Dispensing Drives (Model number P-75120-20) were used with MICROPUMP® pump head part number 81110-0199, model 120-000-110 to meter the oxalic acid and rinse water additions. The pumps are positive displacement gear pumps with $1 / 4$ " FNPT connections. The pumps were accurate, showed good repeatability during testing and can be remotely operated.

\section{DECANTING VIA PUMPING}

CP-2 was decanted by using a MICROPUMP® gear pump to start the decanting, then stopping the pump and opening a bypass valve to allow the solution to siphon into the decant tank. Flow initiation went smoothly for all decants and no entrainment was noted during the decanting process.

\section{REMOTE VIEWING OF PRECIPITATION PROCESS}

A video camera was used to record parts of the precipitation process to determine if remotely viewing the precipitator is feasible. The level in the tank must be visually verified prior to transferring the contents to the melter. In addition, entrainment during the decant process is noted by observation of the settled solids near the decant tube during decanting operations. Observation of these processes was possible with the camera, provided the tank lighting was adequate. 


\section{ATTACHMENT ONE. CP-2 FLOWSHEET}

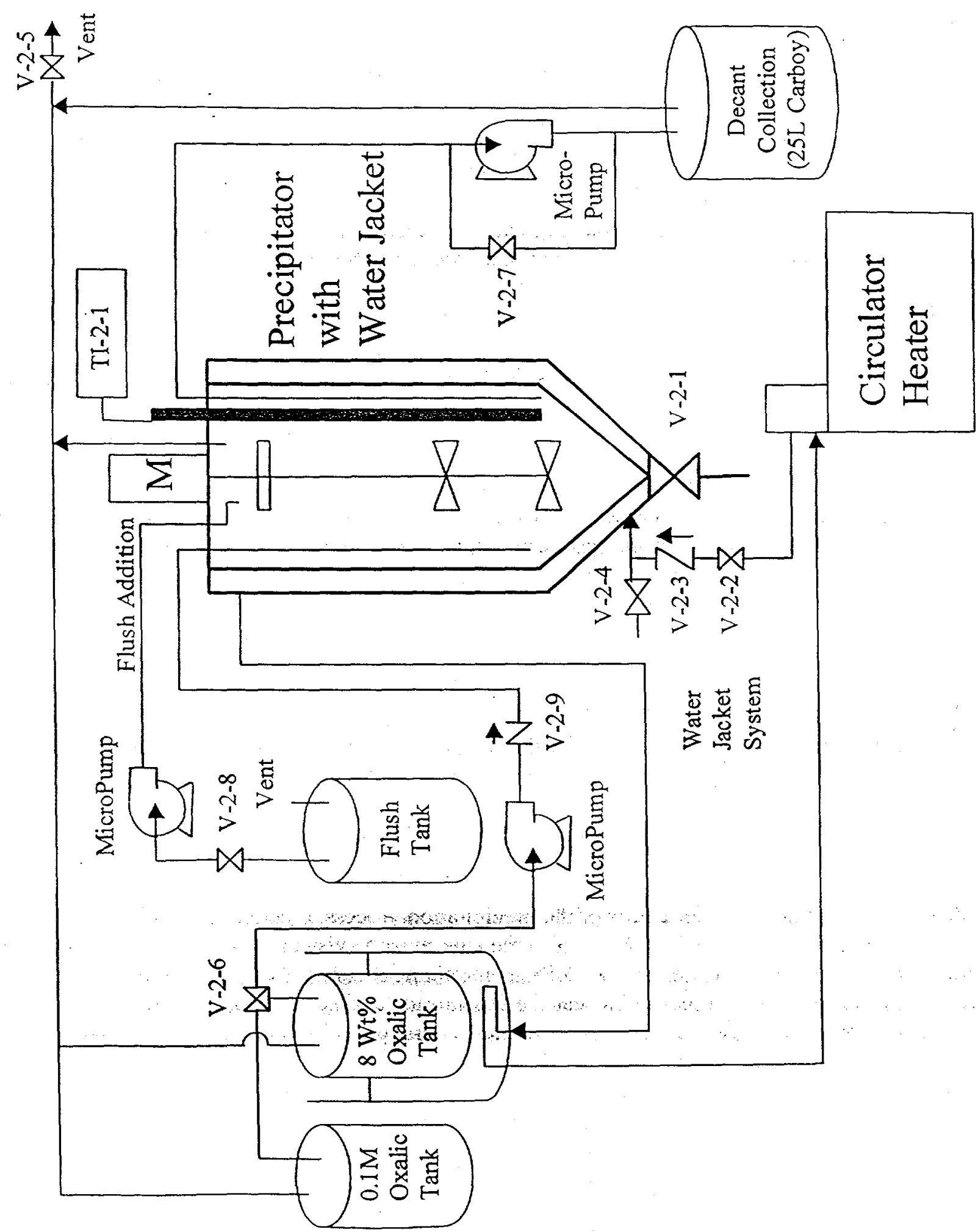


ATTACHMENT TWO. EQUIPMENT SETUP FOR CP-2

\begin{tabular}{|l|l|l|l|l|}
\hline $\begin{array}{l}\text { Run } \\
\text { Number }\end{array}$ & $\begin{array}{l}\text { Oxalic Addition } \\
\text { Method }\end{array}$ & $\begin{array}{l}\text { Drain Pipe } \\
\text { Length }\end{array}$ & $\begin{array}{l}\text { Slinger Ring } \\
\text { Type }\end{array}$ & $\begin{array}{l}\text { Surfactant in } \\
\text { Flush }\end{array}$ \\
\hline CP2-1 & $\begin{array}{l}\text { Subsurface } \\
\text { Feed }\end{array}$ & $2 "$ & Straight-bladed & NO \\
\hline Feed & Fubsurface & $2 "$ & Straight-bladed & NO \\
\hline CP2-3 & Guide Rod & $3.5 "$ & Straight-bladed & NO \\
\hline CP2-4 & Guide Rod & $3.5 "$ & Curve-bladed & NO \\
\hline CP2-5 & Guide Rod & $3.5 "$ & Curve-bladed & NO \\
\hline CP2-6 & Guide Rod & $3.5 "$ & Curve-bladed & NO \\
\hline CP2-7 & Guide Rod & $3.5 "$ & Curve-bladed & NO \\
\hline CP2-8 & Guide Rod & $3.5 "$ & Curve-bladed & $\begin{array}{l}100 \text { PPM } \\
\text { IIT-747 }\end{array}$ \\
\hline CP2-9 & Guide Rod & $3.5 "$ & Curve-bladed & $\begin{array}{l}100 \text { PPM } \\
\text { IIT-747 }\end{array}$ \\
\hline
\end{tabular}




\section{ATTACHMENT THREE. OXALIC ACID GUIDE ROD AND ENTRY TUBE.}

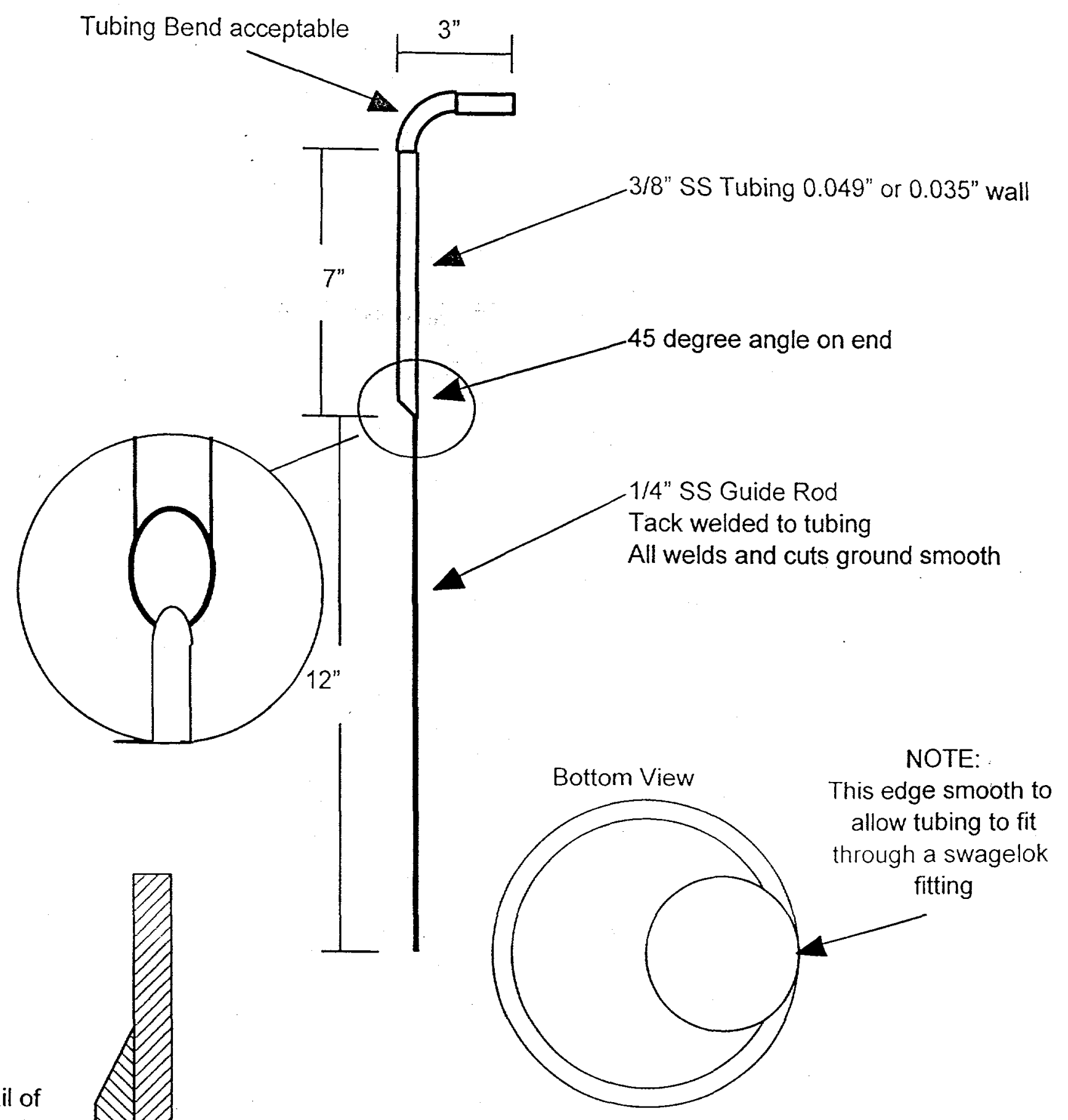
connection etween guide od and tube. 
ATTACHMENT FOUR. CP-2 DRAIN PIPE

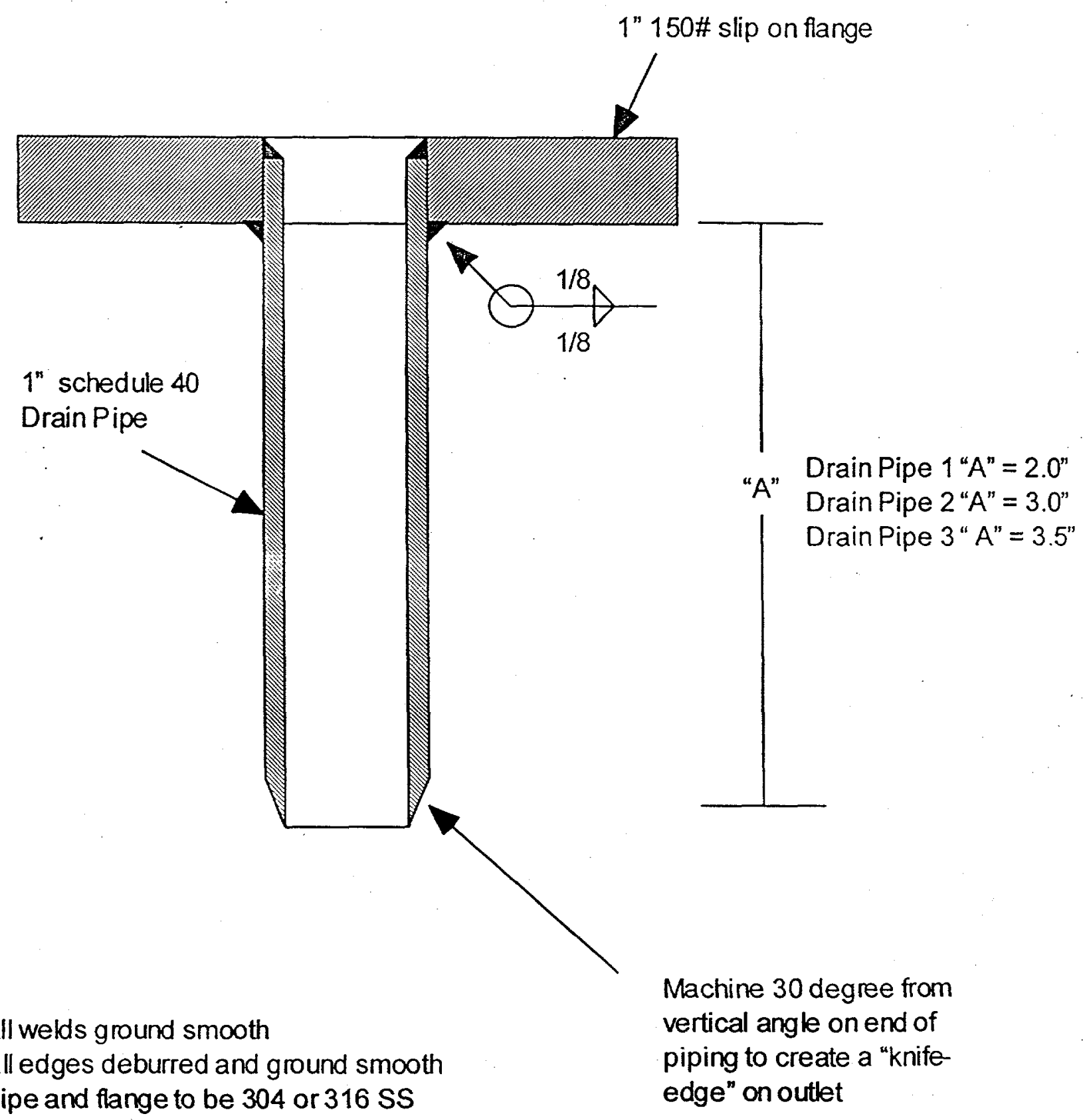


ATTACHMENT FIVE. CURVED-BLADE SLINGER RING
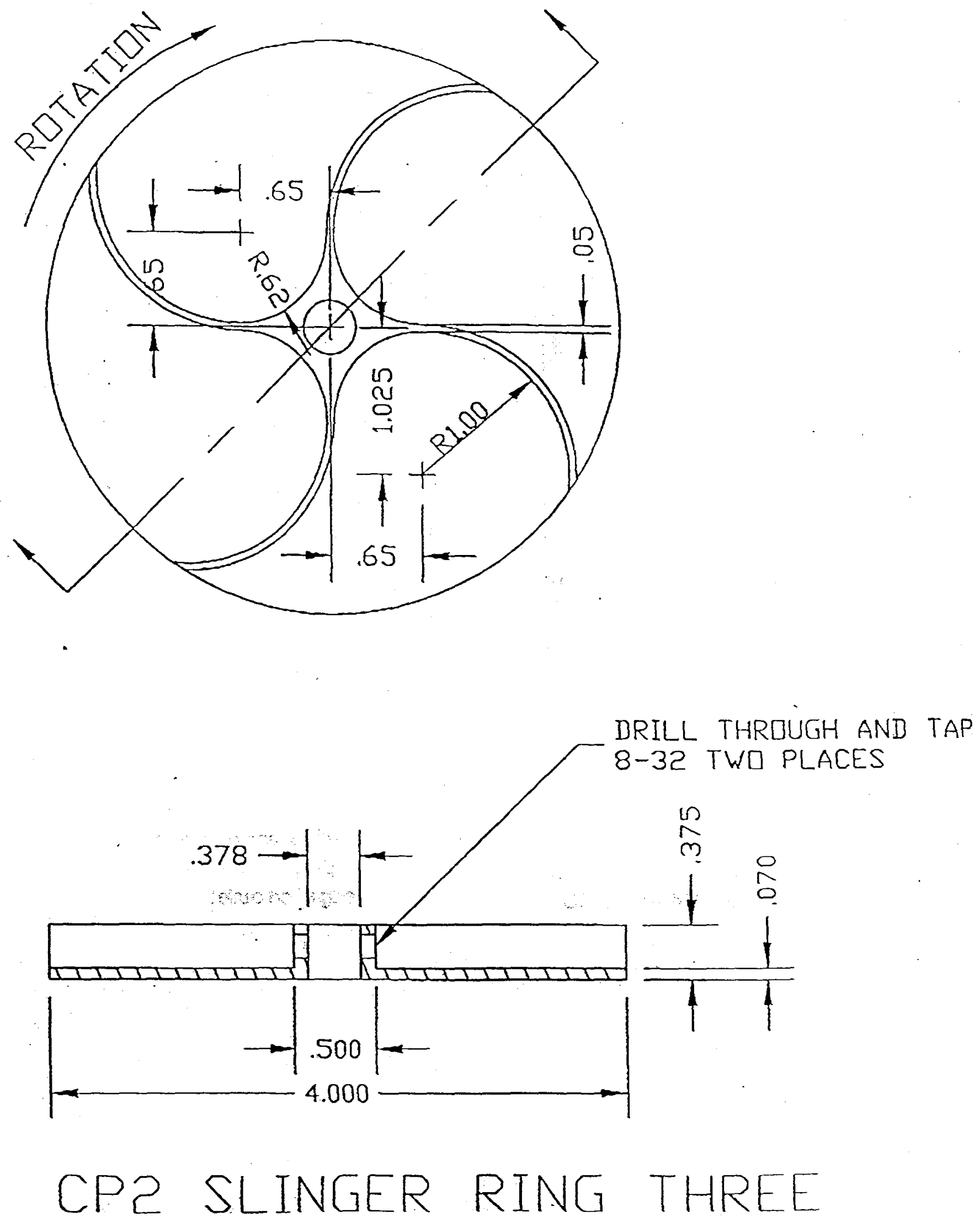
WSRC-TR-99-00284, Rev. 0

Page 10

ATTACHMENT SIX. FLOW DISTRIBUTION OF SLINGER RING

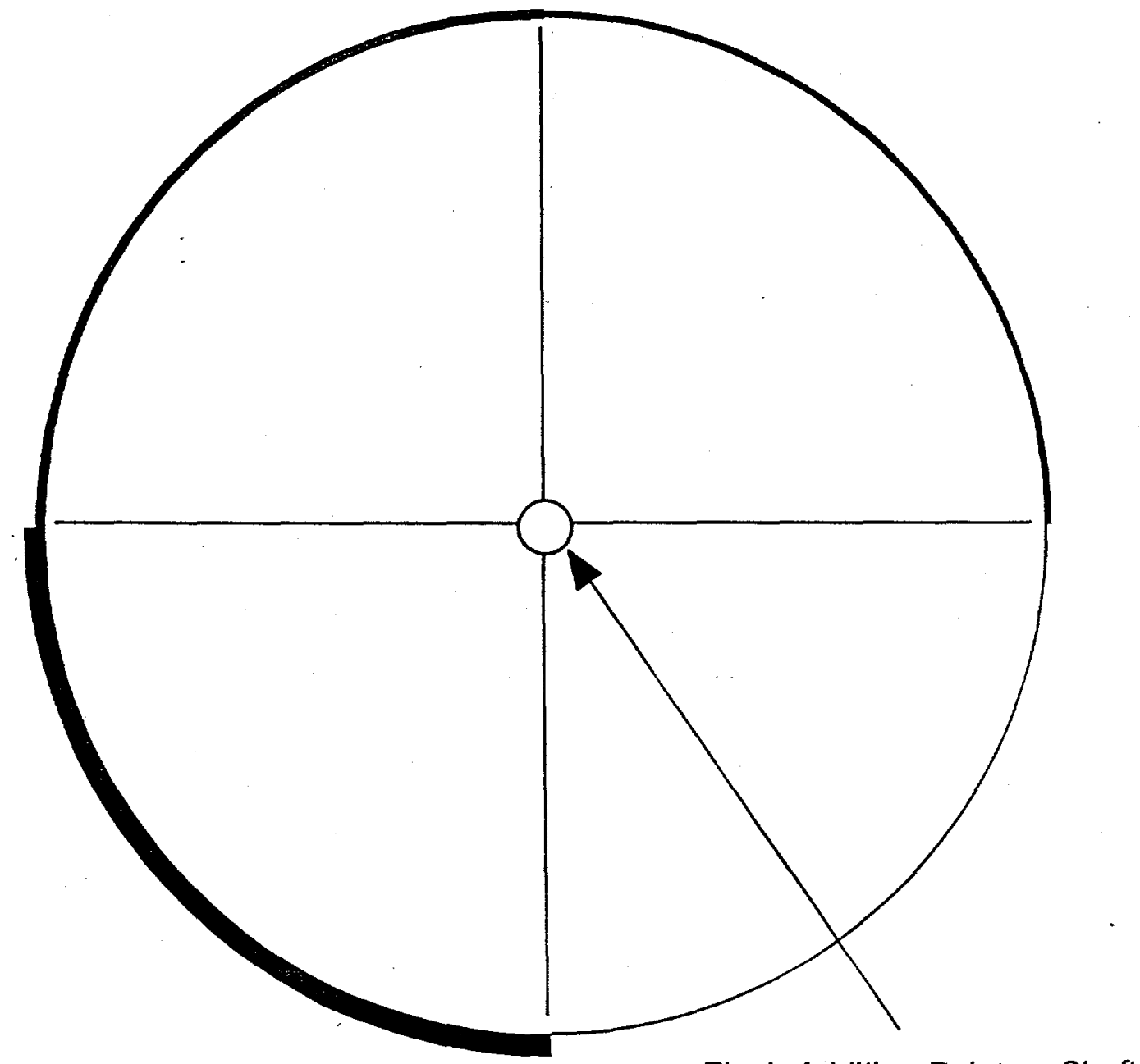

Flush Addition Point on Shaft
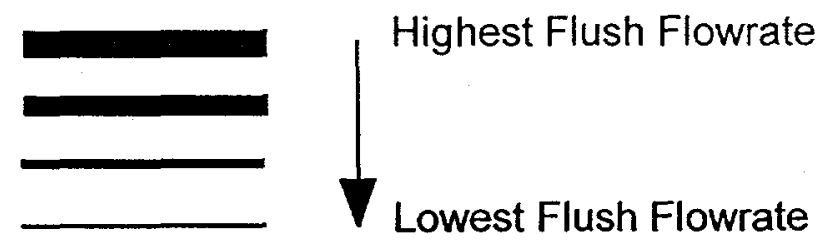
Distribution:

L. F. Landon, 704-1T

J. E. Marra, 704-T

D. C. Witt, 704-1T

W. H. Martin, 730-B

T. M. Jones, 704-1T

D. H. Miller, 704-1T.

T. K. Snyder, 704-T

A. P. Fellinger, 730-B

J. W. Duvall, 704-1T

Am/Cm Files, 704-1T

STI, 703-43A (4) 